\title{
IMPLIKASI KEBIJAKAN PROGRAM PEMBERDAYAAN USAHA GARAM RAKYAT (PUGaR) TERHADAP HASIL PRODUKSI GARAM RAKYAT DI KABUPATEN CIREBON
}

\author{
Nur Hidayah ${ }^{1}$, Dwi Ernaningsih ${ }^{2}$ \\ ${ }^{1,2)}$ Fakultas Perikanan dan Ilmu Kelautan
}

\begin{abstract}
The utilization of marine resources still faces many obstacles to optimize it, including the use of seawater as a raw material for salt production (a type of non-living marine resources). Potency of salt production and demand is expected to increase economic growth of coastal communities. Salt production is done in traditional method that produce salt with low product and less quality, this makes low income for salt farmers. Research was conducted in May - July 2016 to examine the implementation of PNPM PUGAR policies in Kapetakan and Pangenan Subdistrict in Cirebon District. Implementation of PNPM PUGAR policy using bottom-up principle, is based on community proposal through consultation to support goal of national development. PUGAR implementation is already well from planning, implementation, and evaluation. Provision of initial capital for farmers that empowered by program through government assistance can increase quality and quantity of salt production. PUGAR policy is expected to have an impact on poverty reduction to improve the welfare of society as a representation of the national goals in an effort to improve the ability, income, and entrepreneurial growth in marine and fisheries sector.
\end{abstract}

Key word: policy, impact, production, PUGaR

\section{Abstrak}

Pemanfaatan sumberdaya kelautan masih menghadapi banyak kendala dalam mengoptimalkannya, termasuk pemanfaatan air laut sebagai bahan baku garam (salah satu jenis sumberdaya non hayati kelautan). Besarnya potensi produksi dan kebutuhan garam menempatkan garam sebagai komoditas yang diharapkan dapat meningkatkan pertumbuhan ekonomi masyarakat pesisir. Pertanian dilakukan di ladang-ladang garam secara tradisional menggunakan teknologi hasil warisan pendahulunya, dengan menghasilkan produksi dan kualitas garam yang rendah, kondisi ini membuat perekonomian dan pendapatan petambak garam tergolong rendah. Penelitian ini dilaksanakan pada Bulan Mei - Juli 2016, untuk mengetahui pelaksanaan kebijakan PNPM PUGAR yang ada di Kecamatan Kapetakan dan Pangenan, Kabupaten Cirebon. Pelaksananan kebijakan PNPM PUGaR di Kecamatan Kapetakan dan Pangenan, Kabupaten Cirebon menggunakan prinsip bottom-up, yaitu berdasarkan pada usulan yang telah disepakati oleh masyarakat sendiri melalui musyawarah tetapi tidak lepas dari arahan pemerintah pusat sesuai tujuan yang ditargetkan oleh pemerintah. Pelaksanaan tersebut sudah berjalan dengan baik mulai dari perencanaan, pelaksanaan, dan evaluasi. Peningkatan modal awal produksi melalui dana BLM, kualitas produksi meningkat dari KP 3 menjadi KP 2 dan KP 1 diikuti kuantitas garam yang meningkat 2-3 kali lipat dirasakan oleh petambak garam dengan adanya pembinaan, pendampingan serta dukungan peralatan yang modern dalam menghasilkan produksi garam. Kebijakan PUGaR yang dikeluarkan oleh pemerintah diharapkan dapat menimbulkan dampak sesuai dengan tujuan kebijakan PUGaR dalam pengentasan kemiskinan merupakan upaya pemerintah untuk meningkatkan kesejahteraan masyarakat yang berada di bawah garis kemiskinan sebagai bentuk representasi dari tujuan nasional bangsa Indonesia untuk meningkatkan kemampuan dan pendapatan serta pertumbuhan wirausaha kelautan dan perikanan.

Kata kunci: Kebijakan, Dampak, Produksi, PUGaR 


\section{PENDAHULUAN}

Industri garam di Indonesia sudah ada dari jaman dahulu sampai sekarang, teknologi yang digunakan masih tradisional dengan tingkat pendidikan petambak yang masih rendah. Proses produksi garam sangat bergantung pada faktor cuaca, kondisi cuaca menjadi salah satu penentu keberhasilan target produksi garam. Evaporasi air garam dapat tercapai jika didukung oleh radiasi surya serta bantuan rekayasa iklim mikro pada areal pegaraman, khususnya angin, curah hujan, suhu, dan kelembaban, serta durasi penyinaran matahari. Saat ini sudah ada teknologi inovatif untuk meningkatkan kualitas garam yang bisa diterapkan dalam skala usaha garam ditingkat petambak (tepat guna) seperti: sistem ulir, ramsol, geomembran, plastikisasi, bunker, dll). Melalui Program Nasional Pemberdayaan Masyarakat Pemberdayaan Usaha Garam Rakyat (PUGaR) dan bantuan pengembangan usaha dalam menumbuhkan usaha garam rakyat sesuai dengan potensi desa untuk meningkatkan kemampuan dan pendapatan serta pertumbuhan wirausaha kelautan dan perikanan.

\section{Tujuan}

Tujuan yang ingin dicapai dari penelitian adalah:

1. Mengetahui pelaksanaan kebijakan PUGaR yang mampu memperdayakan petambak garam di Kabupaten Cirebon, Jawa Barat.

2. Mengidentifikasi dampak dari pelaksanaan Kebijakan $\mathrm{PUGaR}$ terhadap hasil produksi petambak garam di Kabupaten Cirebon, Jawa Barat.

\section{Manfaat}

Manfaat dari penelitian ini adalah:

1. Secara akademis, hasil penelitian ini diharapkan dapat menjadi referensi bagi penelitian lebih lanjut mengenai Implikasi Kebijakan Program Pemberdayaan Usaha Garam Rakyat (PUGaR) terhadap Peningkatan Hasil Produksi Garam Rakyat di Kabupaten Cirebon.

2. Secara praktisi, memberikan informasi atau masukan kepada instansi terkait sebagai bahan kebijakan dalam memberikan bantuan yang tepat guna untuk petambak garam. Bagi petambak garam, dapat mengetahui dampak yang ditimbulkan dari pelaksanaan kebijakan PUGaR di Kabupaten Cirebon.

\section{Deskripsi Program PUGaR}

\section{TINJAUAN PUSTAKA}

Sejak berabad-abad yang lalu garam dipakai sebagi bumbu penyedap dan pengawet makanan. Seiring dengan kemajuan peradaban, garam telah digunakan sebagai salah satu elemen penting dalam berbagai macam industri. Masyarakat di wilayah pesisir melalui pemilihan mata pencaharian hidup sebagai petambak garam, atau dikenal pula sebagai garam rakyat. Fenomena membanjirnya garam impor menjadikan situasi pergaraman nasional, khususnya garam rakyat semakin terpuruk. Permasalahan ini bermula dari adanya "krisis" garam, karena produksi garam nasional tidak dapat memenuhi kuota kebutuhan garam nasional. Baru pada tahun 2011, dengan Program Nasional Pemberdayaan Masyarakat (PNPM) Mandiri Kelautan dan Perikanan yang disebut PUGaR. Pemerintah membuat suatu 
terobosan kebijakan untuk mewujudkan kesejahteraan masyarakat khususnya di wilayah pesisir. Tujuan utama dari PUGaR adalah mengurangi tingkat kemiskinan dan meningkatkan sumberdaya manusia terutama pada petambak garam. Prioritas PUGaR adalah peningkatan pada kualitas produksi dan produktivitas di tingkat lahan tambak garam (on farm) melalui kapasitas penguatan petambak garam rakyat yang didukung dengan implementasi Teknologi Tepat Guna (TTG), penguatan koperasi, peningkatan partisipasi, tata kelola, pengarusutamaan gender, dan dukungan pemerintah daerah.

\section{Evaluasi Dampak Kebijakan Publik}

Evaluasi kebijakan merupakan usaha untuk menentukan dampak dari kebijakan pada kondisi-kondisi kehidupan nyata pada masyarakat. Subarsono (2013), mengemukakan tentang dampak sebagai berikut, impact (dampak) adalah akibat lebih jauh daripada masyarakat sebagai konsekuensi adanya kebijakan yang diimplementasikan. Evaluasi dampak program harus dicermati bahwa dampak yang terjadi benar-benar sebagai akibat program yang sedang dievaluasi atau justru dampak dari program lain. Dalam kenyataannya seringkali terdapat program pemerintah yang memiliki tujuan yang saling tumpang tindih atau sejenis. Evaluasi dampak memberikan perhatian yang lebih besar kepada output dan dampak kebijakan dibandingkan dengan proses pelaksanaan kebijakan itu sendiri.

\section{METODOLOGI}

\section{Waktu dan Tempat Penelitian}

Penelitian dilaksanakan pada bulan Mei - Juli 2016. Dengan lokasi sampel penelitian di Kecamatan Kapetakan dan Pangenan, Kabupaten Cirebon.

\section{Metode Penelitian}

Penelitian ini adalah metode studi kasus, yang terjadi di Kabupaten Cirebon. Metode yang digunakan adalah metode survei di Kecamatan Kapetakan (2 Desa) dan Pangenan (5 Desa).

\section{Metode Pengumpulan Data}

Data Primer: Pengamatan secara langsung di lapangan/lokasi penelitian dan hasil wawancara/kuesioner.

Data Sekunder: Studi pustaka, literature terkait.

\section{Analisis Data}

Pada penelitian ini menggunakan analisis data deskriptif kualitatif dengan menggunakan studi komparatif dalam mengolah data yang diperoleh, yaitu dengan mereduksi data hasil wawancara, kuesioner dan dokumentasi, data hasil reduksi disajikan dalam bentuk teks naratif, tabel atau gambar, sehingga dapat diambil kesimpulan secara menyeluruh tentang pelaksanaan dan dampak pada kebijakan PNPM PUGaR terhadap hasil produksi garam rakyat di Kabupaten Cirebon 


\section{HASIL DAN PEMBAHASAN}

\section{Pelaksanaan Kebijakan PUGaR terhadap Petambak Garam}

Berdasarkan Peraturan Menteri Kelautan dan Perikanan Nomor PER. 21/MEN/2010 bahwa pelaksanaan kebijakan PUGaR menggunakan prinsip bottom-up, yang dimaksud adalah pelaksanaan kebijakan PUGaR berdasarkan pada usulan yang telah disepakati oleh masyarakat sendiri melalui musyawarah tetapi tidak lepas dari arahan pemerintah pusat dan pengawasan dari dinas kabupaten/kota sesuai tujuan yang ditargetkan oleh pemerintah. Tujuan program PUGaR berdasarkan Buku Pedoman Umum PUGaR adalah meningkatkan produktivitas lahan dan kualitas garam rakyat dan meningkatkan kesejahteraan petambak garam. Pelaksanaan kebijakan dengan memberikan Bantuan Langsung Masyarakat (BLM) kepada petambak garam melalui tahapan pengusulan dan penetapan lokasi sasaran dan penerima BLM PUGaR seperti terlihat pada Gambar 1.

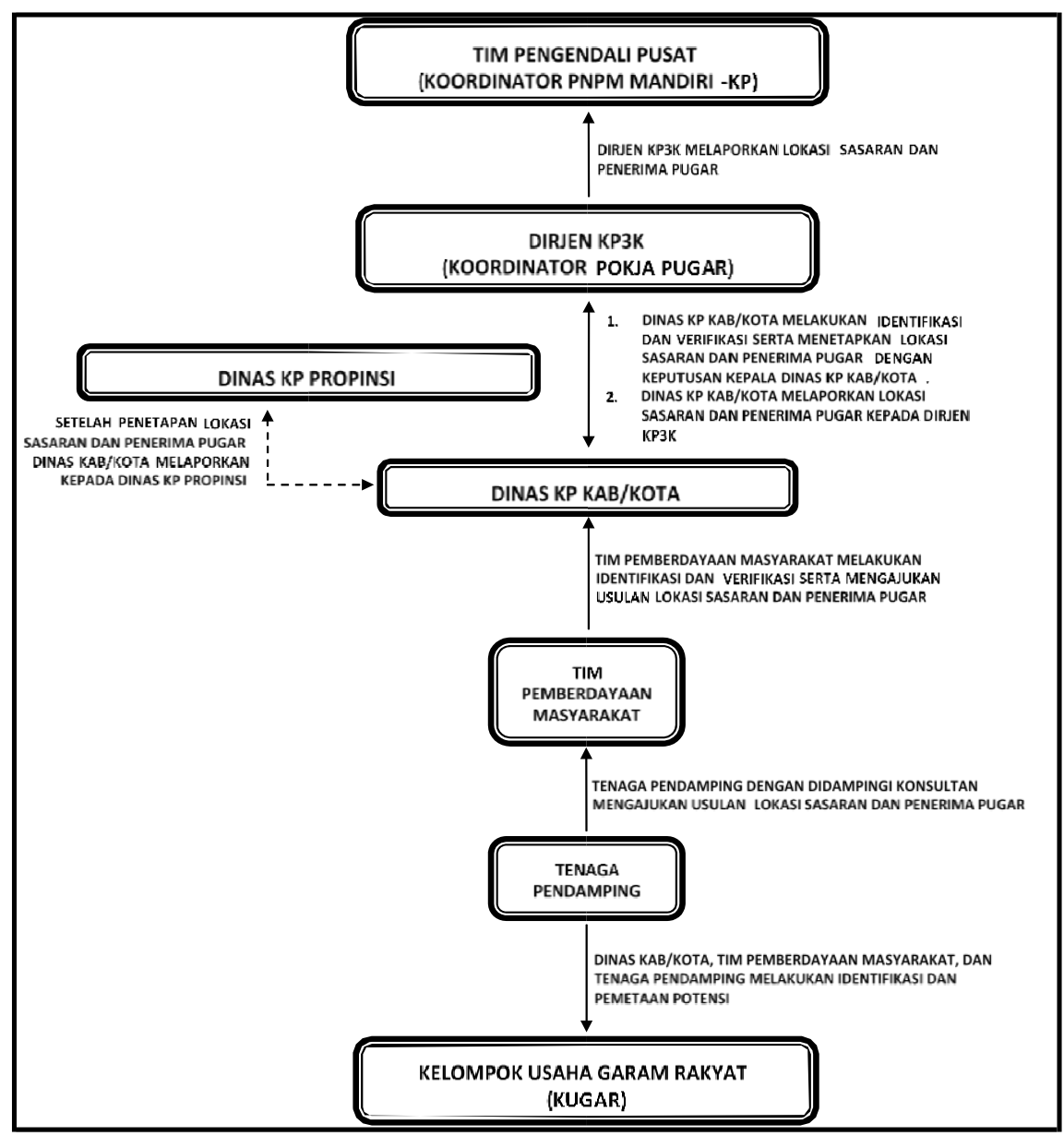

Gambar 1. Tahapan Pengusulan dan Penetapan Lokasi

Dengan adanya bantuan ini petambak dapat mengusulkan bantuan yang dibutuhkan untuk membantu proses produksi melalui Kelompok Usaha Garam Rakyat (KUGAR) sehingg dapat meningkatkan kesempatan kerja dan pendapatan dari hasil produksi garam menuju swasembada garam nasional dalam menanggulangi kemiskinan petambak garam. PUGaR di Kabupaten Cirebon diharapkan mampu meningkatkan kesejahteraan petambak garam.

Pelaksanaan kebijakan PUGaR di Kabupaten Cirebon memiliki dua komponen yaitu ekonomi dan sosial. Kegiatan ekonomi mencakup pemberian akses berupa pemberian BLM kepada petambak garam rakyat Kabupaten Cirebon, sedangkan sosial yaitu memberikan pelatihan, pendampingan, pembinaan kepada petambak garam dengan tujuan menghasilkan peningkatan produksi garam dan peningkatan kualitas garam. 


\section{Partisipasi Kelompok sasaran kebijakan (target group)}

Tahapan yang harus dilaksanakan dalam pelaksanaan kebijakan PUGaR adalah melakukan perencanaan, pelaksanaan dan evaluasi kegiatan yang masing-masing dibutuhkan proses untuk mewujudkan terlaksananya kebijakan PUGaR dengan baik.

1) Perencanaan Kegiatan meliputi: a) Sosialisasi dilakukan oleh Dinas KP Kabupaten Cirebon ke masyarakat untuk mengetahui kesiapan masyarakat tentang adanya bantuan PUGaR di Kabupaten Cirebon. b) Melakukan refleksi kemiskinan bersama perangkat desa untuk mengetahui permasalahan yang dihadapi petambak garam sampai tingkat terendah (desa). c) Pemetaan swadaya dilakukan untuk mengetahui potensi tambak garam yang salah satunya sebagai tumpuan masyarakat Kabupaten Cirebon pada musim kemarau datang. d) Pembentukan organisasi masyarakat menjadi kebutuhan terpenting dalam terlaksananya kebijakan PUGaR. e) Pembentukan Kelompok Usaha Garam Rakyat (KUGAR) berdasarkan musyawarah bersama petambak garam yang disepakati secara mufakat, setiap kelompok beranggota 10 orang petambak garam.

2) Pelaksanaan Kegiatan meliputi: a) Penyusunan Rencana Usaha Bersama (RUB) dan Proposal merupakan rincian program rencana kegiatan dan jumlah nominal dana yang dibutuhkan sesuai dengan sarana prasarana peralatan yang dibuat masing-masing KUGAR untuk melaksanakan PUGaR. b) Pendampingan dilakukan dari awal sampai akhir pelaksanaan PUGaR, pendampingan diberikan mulai dari perencanaan, pelaksanaan dan evaluasi kebijakan yang dilakukan oleh tim fasilitator/tenaga pendamping teknis (TPT) dibawah Dinas KP Kab.Cirebon. c) Pelatihan diberikan untuk membekali petambak garam agar menghasilkan produktivitas garam dengan kualitas terbaik. Pelatihan dilakukan di balai warga atau dikantor kecamatan di setiap lokasi, atau di Dinas KP Kab. Cirebon maupun langsung di lapangan /tambak garam petambak. d) Pembinaan, pengendalian dan pengawasan dilakukan oleh kepala desa sebagai koordinator, tim fasilitator atau TPT, petambak garam dan masyarakat setempat bertujuan untuk memantau, menjaga transparansi dan akuntabilitas serta mengetahui berbagai masalah yang terjadi dalam pelaksanaan kebijakan PUGaR.

3) Evaluasi kegiatan/Pelaporan dan akuntabilitas dilakukan untuk mengukur kebermanfaatan kebijakan yang diterapkan oleh pemerintah. Petambak garam sebagai penerima dana BLM harus dapat menunjukkan kepercayaan yang diberikan kepadanya telah digunakan secara benar dan dipertanggungjawabkan secara terbuka. Petambak garam harus dapat mengelola BLM ataupun peralatan tersebut secara benar, transparan dan akuntabel.

\section{Dampak Kebijakan PUGaR terhadap Petambak Garam di Kabupaten Cirebon}

Penerapan kebijakan pasti tidak lepas dari dampak yang diakibatkan dari penerapan kebijakan tersebut, tidak terkecuali pada kebijakan PUGaR yang diberikan pemerintah kepada petambak garam Kabupaten Cirebon menimbulkan berbagai dampak positif dan negatif. Dampak tersebut dapat dijelaskan sebagai berikut:

1. Dampak Positif meliputi:

a) Bantuan modal pembuatan garam, kemiskinan sangat mudah dijumpai sehingga tidak jarang petambak garam yang memiliki biaya dalam memulai pembuatan garam sehingga harus meminjam uang dari berbagai tempat. Penerapan kebijakan PUGaR di Kabupaten Cirebon yang memberikan bantuan dan dukungan dari persiapan lahan sampai panen diharapkan dapat memberikan harapan kepada petambak garam dalam memulai usaha dalam membuat garam.

b) Peningkatan kualitas garam setelah dilaksanakannya kebijakan PUGaR dengan berbagai program pelatihan, pendampingan, dan pembinaan dapat membuka cakrawala petambak Kabupaten Cirebon sehingga hasil yang diproduksi cenderung lebih putih dan terdapat peningkatan kualitas garam. (lihat pada Tabel 1). 
Tabel 1. Data Perbandingan Harga Garam pada Tahun 2010 dan 2015 Kecamatan Kapetakan dan Pangenan

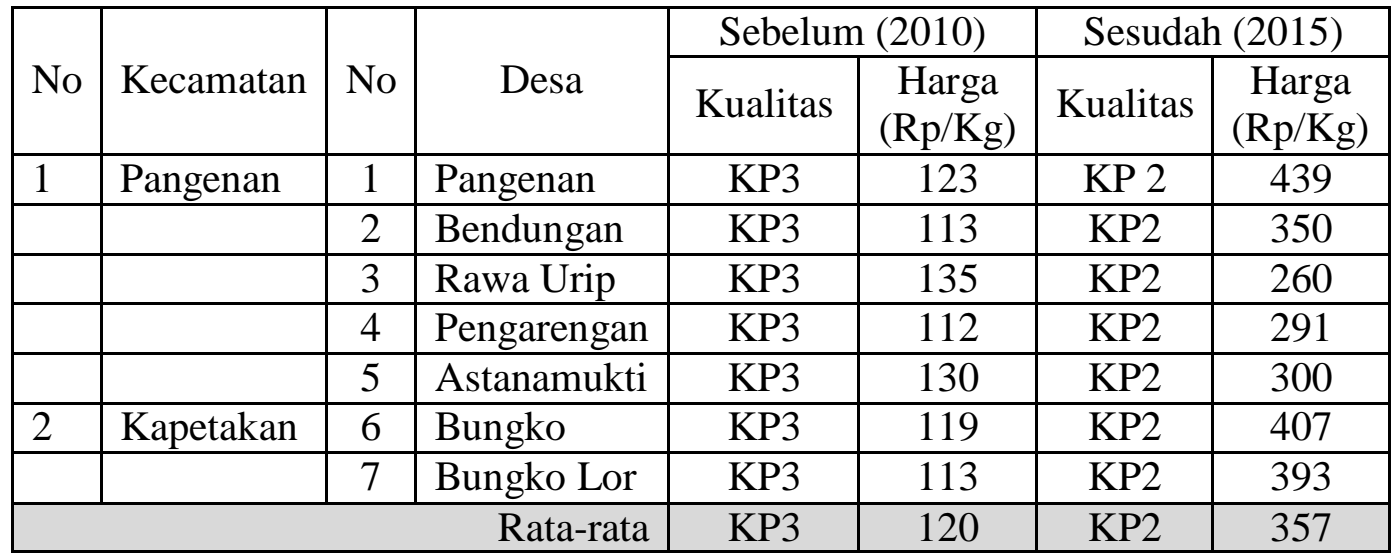

c) Peningkatan produktivitas garam, kondisi sebelum diterapkannya kebijakan PUGaR produksi garam petambak cukup rendah dengan kualitas yang rendah pula. Namun setelah pelaksanaan PUGaR, peningkatan produksi garam sangat dirasakan petambak garam Kabupaten Cirebon yang mendapatkan kebijakan PUGaR. Produktifitas hasil produksi garam di Kecamatan Kapetakan dan Pangenan dapat dilihat pada Tabel 2 dan Data produksi garam Kabupaten Cirebon secara umum tahun 2011-2015 pada Tabel 3.

Tabel 2. Produktifitas Hasil Produksi Garam di Kecamatan Kapetakan dan Pangenan

\begin{tabular}{|c|c|c|c|c|c|c|}
\hline \multirow[b]{2}{*}{ No } & \multirow[b]{2}{*}{ Kecamatan } & \multirow[b]{2}{*}{ No } & \multirow[b]{2}{*}{ Desa } & \multirow{2}{*}{$\begin{array}{c}\text { Luas } \\
\text { Lahan } \\
\text { (Ha) }\end{array}$} & \multicolumn{2}{|c|}{ Produksi (Ton/Ha) } \\
\hline & & & & & Tahun 2010 & Tahun 2015 \\
\hline \multirow[t]{5}{*}{1} & Pangenan & 1 & Pangenan & 1,89 & 39,41 & 81,39 \\
\hline & & 2 & Bendungan & 1,25 & 56 & 122,30 \\
\hline & & 3 & Rawa Urip & 1,40 & 17,50 & 53,21 \\
\hline & & 4 & Pengarengan & 1,27 & 34,64 & 92,86 \\
\hline & & 5 & Astanamukti & 1 & 27,88 & 60,25 \\
\hline \multirow[t]{2}{*}{2} & Kapetakan & 6 & Bungko & 1,19 & 49,35 & 97,42 \\
\hline & & 7 & Bungko Lor & 1,29 & 54,09 & 104,55 \\
\hline \multicolumn{4}{|c|}{ Rata-rata } & 1,30 & 42,27 & 90,04 \\
\hline
\end{tabular}

Data produksi tahun 2011 sampai dengan 2014 tidak dapat ditampilkan secara time series, karena pemberian bantuan BLM PNPM PUGaR tidak hanya terfokus pada satu desa atau kelompok itu saja, penyaluran bantuan ini dapat diberikan untuk lokasi lain yang memiliki potensi lahan garam dengan penambahan jumlah kelompok KUGAR, dengan demikian data produksi pada desa sampel tidak ditemukan secara kontinue setiap tahunnya. Desa tersebut masih bisa mendapatkan bantuan BLM PNPM PUGaR ditahun berikutnya apabila berdasarkan hasil evaluasi masih membutuhkan bantuan dan dilihat dari pelaporan pelaksanaan bantuan kebijakan, apakah bantuan yang diberikan dapat digunakan dengan baik dan tepat sasaran. Jumlah KUGAR yang diberikan bantuan dapat bertambah atau berkurang, hal ini berpengaruh terhadap luas lahan yang bertambah/berkurang serta jumlah produksi yang dihasilkan. Secara umum produksi garam di Kabupaten Cirebon mengalami kenaikan yang cukup tinggi setiap tahunnya, yaitu $\pm 50 \%$, seperti terlihat pada Tabel 3. 
Tabel 3. Data Produksi Garam Kabupaten Cirebon Tahun 2011 - 2015

\begin{tabular}{|l|r|r|r|r|r|}
\hline Tahun & \multicolumn{1}{|c|}{2011} & \multicolumn{1}{c|}{2012} & \multicolumn{1}{c|}{2013} & \multicolumn{1}{c|}{2014} & \multicolumn{1}{c|}{2015} \\
\hline Luas Lahan (Ha) & 1.504 & 3.088 & 4.273 & 3.858 & 3.858 \\
\hline Produksi PUGaR (Ton) & 88.600 & 289.581 & 184.046 & 314.480 & 435.439 \\
\hline
\end{tabular}

d) Petambak garam tidak dipermainkan tengkulak, petambak dapat menyimpan hasil produksi di gudang penyimpanan dan menjual saat harga garam tinggi.

e) Peralatan pergaraman petambak yang semakin modern, pemerintah melaksanakan kebijakan PUGaR kepada petambak garam Kabupaten Cirebon melalui BLM dapat diberikan peralatan yang lebih modern seperti mesin diesel, alat pengukur garam, ramsol, terpal (geoisolator), sistem teknologi ulir filter (TUF) sampai rumah kaca. Penggunaan teknologi tersebut terbukti dapat meningkatkan kualitas dan kuantitas garam.

f) Lebih fokus terhadap pekerjaan membuat garam, BLM merupakan dana stimulant (rangsangan) dari pemerintah yang dijadikan modal bagi petambak melakukan usaha pergaraman, tanpa mencari pekerjaan sampingan lain sebagai modal pertama memulai usaha.

g) Kerukunan petambak garam, seringnya melakukan kontak sosial dalam setiap kegiatan PUGaR seperti bertemu saat sosialisasi, RKM, penyusunan RUB dan lain-lain, membuat petambak garam menjadi akrab dan rasa kekeluargaan menjadi terjalin.

2. Dampak Negatif:

a) Kecemburuan sosial antara petambak garam, timbulnya kecemburuan sosial disebabkan adanya sikap beberapa petambak garam yang ingin mendapatkan BLM PUGaR tanpa menunggu giliran kelompoknya sehingga menyebabkan kecemburuan karena ingin segera mungkin mendapatkan dana bantuan lebih dulu untuk memulai proses pembuatan garam.

b) Petambak garam terlalu mengandalkan BLM PUGaR, sebelum adanya BLM PUGaR petambak garam tetap memulai membuat garam di awal waktu meskipun modal tersebut berasal dari pinjaman, tetapi setelah dilaksanakan kebijakan PUGaR adanya ketergantungan yang dialami petambak garam terlalu mengandalkan bantuan BLM PUGaR dari pemerintah, sehingga saat pencairan BLM terlambat membuat petambak garam juga terlambat memulai pembuatan garam padahal musim kemarau hanya berlangsung selama 5 sampai 6 bulan saja, BLM ini membuat petambak garam tidak mau memulai proses pembuatan garam di lahan tambaknya sampai BLM tersebut cair.

\section{KESIMPULAN}

Berdasarkan hasil penelitian maka dapat disimpulkan bahwa:

1) Kebijakan PNPM PUGaR di Kabupaten Cirebon dengan prinsip bottom-up dan sudah berjalan dengan baik, dengan diimplementasikan melalui 3 tahapan yaitu: perencanaan, pelaksanaan, dan evaluasi.

2) Pelaksanaan Kebijakan PNPM PUGaR di Kabupaten Cirebon menimbulkan dampak positif dan negatif bagi keberadaan petambak garam, sebagai berikut: (a) Dampak Positif: 1) Peningkatan modal awal pembuatan garam, 2) Peningkatan produktivitas garam, 3) Peningkatan kualitas garam, 4) Petambak lebih fokus terhadap pekerjaan sebagai petambak garam, 5) Petambak garam sudah tidak dipermainkan tengkulak garam, 6) Peralatan petambak garam lebih modern, 7) Terciptanya kerukunan petambak garam, (b) Dampak Negatif: 1) Kecemburuan sosial antar petambak garam, 2) Petambak garam terlalu mengandalkan BLM kebijakan PNPM PUGaR. 


\section{Saran}

Berdasarkan kesimpulan yang telah diambil maka dapat direkomendasikan beberapa saran sebagai bahan pertimbangan untuk menentukan langkah selanjutnya dalam merumuskan kebijakan PNPM PUGaR, yaitu:

1) Bagi Pemerintah

a) Kebijakan PNPM PUGaR yang diberikan pemerintah dapat dilaksanakan sampai petambak garam benar-benar terberdaya dalam meningkatkan kesejahteraan. Pemberian BLM hendaknya tepat waktu

b) Perlunya pengembangan infrastruktur untuk mendukung aksesibilitas petambak garam untuk meningkatkan pendapatan.

2) Aktor atau Pelaksana kebijakan PNPM PUGaR

a) Pendampingan tidak hanya berdasarkan pada teori saja tetapi praktiknya kurang, serta tidak menyamakan permasalahan teknis pembuatan garam karena masing-masing petambak memiliki masalah yang berbeda-beda.

3) Petambak garam

a) Penerima kebijakan seharusnya saling memahami tanpa adanya sifat cemburu satu dengan yang lain.

b) Petambak garam hendaknya tidak bergantung dan mengandalkan BLM dari pemerintah sehingga apabila bantuan terlambat cair maka perpengaruh terhadap produksi yang dihasilkan tidak maksimal.

\section{DAFTAR PUSTAKA}

Badan Pusat Statistik Kabupaten Cirebon. 2015. Statistik Kecamatan Kapetakan Tahun 2015.

Badan Badan Pusat Statistik Kecamatan Cirebon. 2015. Statistik Kecamatan Pangenan Tahun 2015.Bappeda Kabupaten Cirebon. 2014. Rencana Pembangunan Jangka Menengah Daerah(RPJMD) Kabupaten Cirebon Tahun 2014-2019.

Dinas Kelautan dan Perikanan Kabupaten Cirebon. 2015. Laporan Akhir Tenaga Pendamping PUGaR.

Dinas Kelautan dan Perikanan Kabupaten Cirebon. 2015. Laporan Tahunan Dinas Kelautan dan Perikanan Kabupaten Cirebon 2015.

Direktorat Jenderal Kelautan Pesisir dan Pulau-Pulau Kecil. 2014. Petunjuk Teknis Implementasi Teknologi Ulir Filtrasi (TUF) Isolator dan Pembangunan Gudang.

Direktorat Jenderal Kelautan Pesisir dan Pulau-Pulau Kecil - Direktorat Pemberdayaan Masyarakat Pesisir dan Pengambangan Usaha. 2015. Petunjuk Teknis PUGaR.

Direktorat Jenderal Pengelolaan Ruang Laut - Direktorat Jasa Kelautan. 2016. Petunjuk Teknis PUGaR

Direktorat Jenderal Pengelolaan Ruang Laut. 2015. Laporan Kegiatan Pendataan Garam Tahun 2015

Setyaningrum. 2015. Tingkat Pemberdayaan Usaha Garam Rakyat (PUGAR) ditinjau dari Aspek Produksi, Distribusi, Permintaan Pasar dan Sosial Budaya. Fakultas Teknik. UNDIP

Sulistiyani. 2015. Dampak Kebijakan Program Nasional Pemberdayaan Masyarakat Pemberdayaan Usaha Garam Rakyat (PNPM PUGaR) Terhadap Petani Garam Desa Kedungmutih Kecamatan Wedung Kabupaten Demak. Fakultas Ilmu Sosial. UNY 